\title{
Contents, Vol. 211, Supplementary, 1997
}

\section{Contents Vol. 211, Suppl. 1, 1997}

1 Preface

Honda Y. (Kyoto); Behrens-Baumann, W. (Magdeburg)

2 Antibacterial Protection of the Ocular Surface

Pleyer, U.; Baatz, H. (Berlin)

9 A New Perspective in Ocular Infection and the Role of Antibiotics

Miyanaga, Y. (Tokyo)

15 Antibiotic Sensitivity of Recent Clinical Isolates from Patients with Ocular Infections

Ooishi, M.; Miyao, M. (Niigata)

25 Treatment of Chlam $\gamma$ dial Conjunctivitis

Nakagawa, H. (Tokyo)

29 Treatment of Herpetic Keratitis with Acyclovir: Benefits and Problems

Ohashi, Y. (Ehime)

33 Topical Antimycotics in Ophthalmology

Behrens-Baumann, W. (Magdeburg)

39 Acanthamoeba Keratitis

Ishibashi, Y. (Tokyo)

45 Local Immune Responses in Ocular Virus Infection and Their Implications for Future

Immunotherapy

Hayashi, K. (Kobe)

53 Opportunistic Infections of the Eye in Immunocompromised Patients

Guembel, H.O.C.; Ohrloff, C. (Frankfurt)

62 Preoperative Disinfection of the Conjunctival Sac in Cataract Surgery

Hara, J.; Yasuda, F.; Higashitsutsumi, M. (Osaka)

68 Prophylactic Use of Topical Anti-lnfectives in Ophthalmology

Kramer, A. (Greifswald); Behrens-Baumann, W. (Magdeburg)

77 Local Antimicrobial Prophylaxis in Cataract Surgery: Recent Controversies and Clinical Guidelines

Adenis, J.P.; Robert, P.Y. (Limoges)

Author Index

Subject Index

KATVGER C1997S. KargerAG, Basel V

E-Mail karger@karger.ch The list of contents is available at:

F. Fax + 41613061234 http://www.karger.ch/journals/oph/ophcont.htm

http://www.karger.ch 